\title{
SOCIAL ENTERPRISE IN TRANSITION: A CASE STUDY OF ACT GROUP
}

Paul STUBBS

The Institute of Economics, Zagreb

Davorka VIDOVIĆ

Faculty of Political Science, Zagreb

UDK: 330.526.36(497.524Čakovec)

Izvorni znanstveni rad

Primljeno: 16. 11. 2016.

Contextualising the lived practices of social enterprises overcomes crude binaries between the idealised views of such ventures as 'heroic' and those which see them as the reproduction of neo-liberal hegemony. When translated into 'transition' contexts in the 'semi-periphery', there is a need for case studies of social enterprises which address the micro-level of lived social practices, exploring the ways in which particular initiatives steer a path, however contradictory and paradoxical, towards an autonomous space for action, even in the face of an inconsistent and unsupportive operating environment. Based on a 'bending and blending' approach, making a virtue out of the fact that researchers on social enterprises inevitably are also enrolled as policy consultants, advisors, advocates, and practitioners, this paper uses qualitative methods to explore the work of ACT Group, a consortium of social enterprises from Čakovec, Croatia. The text explores the hybrid nature of the Group's organisational topography and leadership styles, the complex relationship between informal and formal practices, and the unexpected synergies between charismatic leadership and collective decision-making.

Keywords: social enterprise, Croatia

Paul Stubbs, The Institute of Economics,

Trg J. F. Kennedyja 7, 10000 Zagreb, Croatia.

E-mail: pstubbs@eizg.hr 


\section{BEYOND THE BINARY BIND: REFLECTING ON SOCIAL ENTERPRISE IN THE CORE AND SEMI-PERIPHERY}

Social enterprises and the social economy more generally, coinciding with the undermining of the traditional 'welfare state', have become increasingly important in Europe and beyond, in recent years. Exhibiting a wide range of forms, social enterprises share a common aim "to base a business on principles different than those connected merely to profit" (Šimleša, Puđak, Majetić, \& Bušljeta Tonković, 2015a, p. 10). Writings on social enterprise remain somewhat abstract with few in-depth case studies beyond descriptions of 'the usual suspects', a small number of initiatives which have gained international recognition. In addition, the literature tends to be trapped in what might be termed a 'binary bind'. The majority of texts still tend to an idealised view of social enterprise as 'heroic' and 'pioneering' (Leadbeater, 1997; Bornstein, 1998). On the other hand, a smaller, critical literature sees in social enterprise yet another example of the reproduction of neoliberal hegemony (Cook, Dodds, \& Mitchell, 2003; Eikenberry \& Kluver, 2004; Lloyd, 2007).

Whilst it is apparent that the recent upsurge of interest in social enterprise coincides with neoliberal restructurings of the economy, politics and society, including the shrinking of the welfare state, the connections and causal linkages between processes of neoliberalization and the rise of social enterprises is by no means automatic and clear cut. There is little to be gained from discussing the linkage in vague, general terms. Rather, it needs to be explored in specific contexts and conjunctures. Indeed, just as we should be sceptical regarding whether there is any such thing as 'social enterprise' in general, it is important to go beyond the idea that there exists in any meaningful empirical sense a single, unified, all-encompassing and all-conquering 'neoliberalism'. Neoliberalism is "a situated, hybrid project that takes multiple forms in multiple places" (Larner, 2015, p. 195). The danger of 'flattening' (Newman, 2012, p. 157) the concept of neoliberalism occurs when no distinction is made between neoliberalism as an ideology, as a political practice, as a set of policy prescriptions and as a mode of governance or technique of governmentality. Flattening neoliberalism is in danger of becoming "the next-generation 'globalization' concept" (Clarke, 2008, p. 137) with too little attention paid to "the different modes of insertion into 'global' neo-liberalism that are experienced by different regions, nations and more local places" (Clarke, 2008, p. 137).

Paying more attention to the specifics of the "transnational relations through which such insertions are conducted" (Clarke, 2008, p. 138), allows us to explore social enterprise in the 'node' of Central, Eastern and South Eastern Europe, and 
DRUŠ. ISTRAŽ. ZAGREB GOD. 26 (2017), BR. 2 STR. 143-163

STUBBS, P., VIDOVIĆ, D.: SOCIAL ENTERPRISE...
Croatia in particular, as "complicated, multiple, hesitant, and ambiguous" (Clarke, 2008, p. 138). Local articulations of 'global' phenomena such as social enterprise, then, are always 'translations', part of "a selective and active process in which meanings are interpreted and reinterpreted to make them fit their new context" (Clarke, Bainton, Lendvai, \& Stubbs, 2015, p. 35). In this way, "the focus of analysis shifts to how multiple projects coexist and how contradictions between them are resolved in particular sites at specific moments, and what forms of labour are at stake." (Newman, 2012, p. 158, emphasis in original).

This is not to deny a kind of 'elective affinity' (Fraser, 2009) between the rise of social enterprises and 'disorganised' or 'flexible' capitalism, notably as a supplement for or even alternative to the hollowed-out, residualised, responsibilised and shrunken welfare state. Social enterprises fit all too well with a 'moral economy' of volunteering in low-employment states (cf. Muehlebach, 2012), and are entirely compatible with the increasing precaritisation and flexibilisation of the labour market even for the educated middle classes. And yet, at times these affinities may be more 'perverse confluences' (Dagnino, 2007) with strands of the social enterprise movement, not unlike earlier strands of 'new social movements' being built on some kind of critique of consumerist capitalism and, at times, representing utopian-like experiments in alternative social organisation.

Not only have many actually existing social enterprises developed from social movement activism, but also social movement theory offers a different challenge to "the heroic individual model" (Spear, 2010, p. 2) of social entrepreneurship, emphasising collective mobilisations which may not be entirely 'capitalocentric' (Gibson-Graham, 2006). Gibson-Graham have been pivotal in imagining and exploring "an expansive and generative politics of noncapitalist construction" (Gibson-Graham, 2006, p. 53). Although deliberately not seeking to map the contours of a "ready-made alternative economy" (Gibson-Graham, 2006, p. 60), their conceptualisation of the 'radical diversity' of economic relations in terms of three interlinked practices: different kinds of transaction; different types of labour and compensation; and different types of enterprise (Gibson-Graham, 2006, p. 60), offers a clear starting point for an understanding of social enterprise as a potentially counter-hegemonic form.

Gibson-Graham's three practices form a coherent analytical lens through which to discuss social enterprises in conjunctural contexts. Thinking conjuncturally, in Clarke's (2010) terms, involves analysing the diverse and sometimes divergent tendencies at work in a particular temporal and spatial 
DRUŠ. ISTRAŽ. ZAGREB GOD. 26 (2017), BR. 2, STR. 143-163

STUBBS, P., VIDOVIĆ, D.: SOCIAL ENTERPRISE... context. Although it is the differential configuration of ownership and production in communal, nonprofit and co-operative enterprises which marks out many social enterprises, the importance of unpaid and alternatively paid labour in family care, neighbourhood and volunteer work, co-operative and reciprocal labour, for example, should not be automatically seen as contributing to neoliberal hegemony. Similarly, non-market and alternative market exchange, including gifts, ethical fair trade, local trading systems, alternative currencies and the like, may be socially negotiated outside of the laws of supply and demand and under conditions which are not those of profit maximisation.

Larner's example of the Coexist project, emerging in the aftermath of the 2008 financial crisis, shows the possible radical co-presence of autonomy and anti-authoritarianism, with key activists occupying "multiple roles and ... building 'portfolio careers' across diverse activities and interests" (Larner, 2015 , p. 200), operating through "collaborative forms of leadership and management structures" and fostering 'skill-sharing' (Larner, 2015, pp. 200-201). As an anarchist-inspired form of 'prefigurative politics', what is perhaps most interesting about Coexist is the attempt to reclaim from neoliberalism the concept of 'creativity'. As Larner argues:

"(T)he explicit performance of creativity (which can be environmental, economic or cultural) and the patterns of labour associated with that performance are not understood as neoliberal exploitation but rather as an expression of 'living differently'. ... (I)n many of these new organisational and occupational strategies attributes like communication, affect, opinion, attention and taste are actively engaged" (Larner, 2015, pp. 201-202).

In a sense, different claims to and performances of 'creativity' have to be studied empirically, as the 'creative economy' both expands opportunities for a wider group of young people in important fields and can serve to "disguise the normalisation of under-employment" (McRobbie, 2011, p. 33). A scepticism regarding the political potential of 'social enterprise' as a panacea, not unlike a scepticism regarding the potentials of 'civil society', not least when reduced to the modernised, professionalised and elitist 'non-governmental organisation' (Stubbs, 2012), should not allow us to neglect real contradictions and the possibilities of re-claiming what McRobbie herself refers to as "a creative ethos of social care and compassion" (McRobbie, 2011, p. 33).

Assessing the potential of social enterprise to "overcome the dualism between market and social progress; doing good by using the market as a vehicle" (Olma, 2016) demands detailed case studies. There is no inherent contradiction between 'en- 
DRUŠ. ISTRAŽ. ZAGREB GOD. 26 (2017), BR. 2 STR. 143-163

STUBBS, P., VIDOVIĆ, D.: SOCIAL ENTERPRISE... trepreneurial innovation' and 'social innovation', therefore even if the latter sometimes evolves to tackle the very problems created by the former. It may be the case, empirically, that "much of social entrepreneurship fails its own entrepreneurial aspirations by massively relying on sponsors and government subsidies" (Olma, 2016), but judging social entrepreneurship solely in terms of the standards of capitalist market competition is to miss the point. In a sense, whilst Corporate Social Responsibility involves "the embedding of ethics within commercial rationalities" (Dolan \& Rajak, 2016, p. 3), social enterprises involve the use of "entrepreneurial dynamics" (Defourney \& Nyssens, 2010, p. 42) to achieve a "social or societal objective" (European Commission, 2011).

It is important to trace what happens when the concept of 'social enterprise' is translated from the European core to the 'semi-periphery'. 'Semi-periphery' is used here in Marina Blagojević's sense (Blagojević, 2006) to refer to those parts of wider Europe, including Croatia, which have experienced and are still subject to a kind of 'contradictory modernisation' constructed as a kind of 'semi-Other' in relation to an 'imagined West'. Semi-peripheral spaces are, simultaneously, like the West and not like the West, existing in an intermediate position between the so-called First and Third Worlds. Crucially, the path to modernisation is both paradoxical and takes place in perverse conditions, particularly in the context of so-called post-communist 'transition', of deindustrialisation, repatriarchalisation and often, authoritarian nationalism. Symbolically, then, Blagojević argues, this creates deep ambivalence, a kind of "simultaneous opposition and acceptance, imitation and rejection" (Blagojević, 2006) of externally-driven schemes of 'progress', 'reform' and 'modernisation'. The very idea of 'European integration' feeds off and contributes to this very ambivalence (cf. Krajina \& Blanuša, Eds., 2016). The building of 'consolidated democracies', 'free markets' and, of course, 'sustainable civil society' is thus riddled with contradictions. The push for 'social enterprise' as a kind of second- or third-wave reform project feeds into the same ambivalence, translated from the centre as a new trend-based social engineering and the new 'golden key' to sustainable development and well-being for all. Following a rush to 'build civil society', a focus on 'building social enterprises' continues to encourage a quite rational instrumentalisation of the concept by local actors who are able to use the concept flexibly for their own purposes.

Our concern here, in addressing one group of social enterprises in Croatia, is to address the importance of informal social relations acting as "powerful determinants of behaviour within and among organizations" (Chisholm, 1989), and as effective instruments in coordination (Chisholm, 1989). We 
DRUŠ. ISTRAŽ. ZAGREB GOD. 26 (2017), BR. 2, STR. 143-163

STUBBS, P., VIDOVIĆ, D.: SOCIAL ENTERPRISE... explore the complex relationship between a formal absence of hierarchy and the informal hierarchies which develop when organisational structures are dominated by individual charismatic founder-leaders. Whilst the individual characteristics of leaders have been seen as crucial for the long term success of social enterprises (Leadbeater, 1997; Bornstein, 1998), there are debates regarding the relative merits of individual as opposed to collective leadership (Defourny \& Develtere, 1999). Sometimes the founder's role can lead to behaviour commonly recognised as 'founder's syndrome' (Block, 2004) with negative effects on an organisation's sustainability. At the same time, a 'gifted' and 'charismatic' leader may be crucial in maintaining the mission of an organisation and in empowering its members (see McMahon, 2008).

Whilst recent overviews of the development of social entrepreneurship in Croatia suggest that "we are behind both Europe, and a great part of the world" (Šimleša, Puđak, Majetić, \& Bušljeta Tonković , 2015b, p. 75), not least in terms of the absence of a supportive and enabling legal and policy environment and lack of a clear strategic vision (Vidović, 2013), our focus here is less on an analysis of the macro-level conditions for social enterprise in Croatia and more on the micro-level of lived social practices, exploring the ways in which particular initiatives steer a path, however contradictory and paradoxical, towards an autonomous space for action, always richer and more varied than when discussed as an example of 'best practice' or as a 'success'.

\section{RESEARCHING SOCIAL ENTERPRISES: REFLEXIVITY, CASE STUDIES AND 'BENDING AND BLENDING'}

The text utilises qualitative case study methods to describe and analyse a set of social enterprises in Croatia, known as ACT Group, based in Čakovec in the east of Croatia. In blurring the boundaries between 'participation' and 'observation', we utilise a 'bending and blending' approach (Lendvai \& Stubbs, 2007) more akin to 'hunter gathering' (Gould, 2004), which seeks to break down the boundaries between researchers and research subjects by combining different positions and perspectives (Lendvai \& Stubbs, 2007). Taking its departure point from a study mapping key actors, discourses and institutional frameworks in the emerging sector, viewing social enterprise in Croatia as a hybrid phenomenon between traditional 'sectors' of the state, market and civil society (Vidović, 2012), we focus on a particular case to illustrate the complexities beyond the 'binary bind' discussed above.

A commitment to 'bending and blending' takes enrolment in roles such as policy consultant, advisor, advocate and 
DRUŠ. ISTRAŽ. ZAGREB GOD. 26 (2017), BR. 2 STR. 143-163

STUBBS, P., VIDOVIĆ, D.: SOCIAL ENTERPRISE... practitioner in social enterprises in Croatia, not as a barrier to 'objective' research but as a resource generating insights which are capable of being translated analytically. Crucially, a close relationship formed with ACT Group is reconstructed here not as 'objective truth' but rather as a "coherent and plausible story" (Stubbs, 2015, p. 67). As the intensity of contact and multiplication of roles and interconnections with ACT Group increased, a stock of knowledge was accumulated which has hopefully enabled comprehensive, contextualised and in-depth insights into the development of a social enterprise and its social, cultural and symbolic meanings and characteristics, capturing the multifaceted changing dynamics of the group's own organisational development. In reality, many of those who write on social enterprises in Croatia or elsewhere share a similar positionality but this is often masked or played down in written accounts which can resemble "a view from above or from nowhere" (Marcus, 1995). Reflexive 'bending and blending' based on extensive, uneven, fragmented and yet at times intense interconnectedness is, in our view, often preferable to spatially and temporally bounded 'fieldwork', jettisoning a narrow, pre-defined, predictable research design in favour of an approach yielding a less predictable, but no less valid set of insights.

This attempt to explore social enterprises in Croatia from a 'critically reflexive location', or to tell a kind of 'critical cultural story' (Spry, 2009, p. 603), aspires to a kind of 'peopled ethnography' (Fine, 2003), recognising that "the situational intuition and embodied knowledge" of the researcher are "inadequate tools for situating ... observations in a broader social, political and economic context" (Gould, 2004, p. 20). Even through a single case study, it should be possible to move towards what Dorothy Smith has termed 'institutional ethnography', 'making visible' how individual agents "are connected into the extended social relations of ruling and economy and their intersections" (Smith, 2005, p. 29). This sensitivity to "what happens as accounts move from individual experience to explore the social relations in which that experience is embedded" (Newman, 2012, p. 12), alerts us inevitably to "areas of struggle and contestation" (Newman, 2012, p. 12).

The methodological approach is broadly that of an exploratory qualitative study with a longitudinal dimension. The case study of ACT Group presented below is based on extensive empirical material gathered between 2009 and 2016, blended together from participant observation, in-depth interviews with some 15 people, four of whom were interviewed more than once, narrative research and analysis of key discursive texts, from the organisation's many documents and 
DRUŠ. ISTRAŽ. ZAGREB GOD. 26 (2017), BR. 2, STR. 143-163

STUBBS, P., VIDOVIĆ, D.: SOCIAL ENTERPRISE... artefacts (statutes, founding documents, regulations, reports, press releases, and so on). Those interviewed included the Group's founders, managerial staff and employees in different ventures. The interpretation was based on standard qualitative analysis, where coding and categorizing provided identification of the main patterns. Given that ACT Group is the only consortium of social enterprises in Croatia, it has proved impossible to maintain anonymity. Testimonies by individual informants have been anonymised in line with established research ethics and an initial draft of this paper was commented on and approved by a senior ACT representative.

The case is presented in two parts. The first presents a short history of ACT Group, chronicling four main stages in their development, in terms of internal and external dynamics. The second analyses three key elements which were identified during the research as crucial: the attempt to preserve an 'oppositional' identity; the attempt to maintain 'non-hierarchical' organisational structures; and the role of charismatic leadership. A concluding section sets these themes in a wider context and addresses future research priorities regarding the study of social enterprises in Croatia.

\section{THE ACT GROUP CASE}

\section{The background story - history and context}

The Autonomous Centre - ACT was one of the pioneers of social enterprise in Croatia, its formation coinciding with the beginning of social entrepreneurship discourse around 2003. The nascent stage of pioneering social enterprise witnessed uncertainty and fluctuation in the sector, with many social enterprises emerging and then disappearing. Others have managed to survive and continue to operate, but have remained as small-scale ventures with few employees, never growing or 'going to scale'. Autonomous Centre - ACT has not only managed to survive but has grown significantly in terms of membership, staff employed, revenues, and 'spin-off' entities established, which resulted in the forming of the consortium ACT Group. As such, they are something of an exception not only in Croatia, but also in wider South East Europe. In part at least, ACT's resilience, endurance and growth can be traced to the ways ACT Group responded to changes in the internal and external environment. Our concern is to go beyond the surface features of ACT Group to grasp the social, cultural and symbolic significance of key elements that underpin their social enterprise practices in a transition context.

Today, ACT Group is a Consortium of eight social enterprises based in Čakovec, a small town in the north-west of 
DRUŠ. ISTRAŽ. ZAGREB GOD. 26 (2017), BR. 2 STR. 143-163

STUBBS, P., VIDOVIĆ, D. SOCIAL ENTERPRISE...
Croatia with around 15,000 inhabitants. In total, the enterprises employ 45 workers and have an annual revenue of around 950,000 Euro. Some $55 \%$ of their revenue is generated through economic activities. In 2015, they made a profit of some 60,000 Euro, or $6 \%$ of revenue. Almost half of the ACT Group's employees are persons coming from vulnerable social groups, mainly people with disabilities.

As noted above, it is possible to distinguish between four main, if overlapping, stages of the development of ACT Group: from a radical NGO, through an initial definition as a 'social enterprise', to the consolidation of 'social entrepreneurship' as its core mission; and subsequently to the creation of ACT Group as a consortium. Each of these stages are discussed, in broad brush stroke terms, below.

\section{NGO days and ideological origins}

"Well, everything started ... you know when you are young and want to change the world... (laughs). When I look back and see - Wow! - We did make a change in the local community. You can't change the world, but you can change the local society. And that's how the world changes." (Informant 1, managerial position, 2015)

The Autonomous Centre - ACT was founded as a non-governmental organisation, or association of citizens, in 2003 by six individuals, two of whom are still involved in the ACT Group. Some of the founding members were there just to fulfil administrative requirements, but were never really active in the organisation. However, soon after its establishment others became involved with $\mathrm{ACT}$, forming a core network which exists to date. ACT was a small organisation, one of the rare civic initiatives in the north-western part of Croatia at that time. A group of young well-educated friends and acquaintances in their early twenties had all returned from studies abroad or from larger university cities in Croatia. Together, they were eager to transplant part of the progressive world they had experienced away from Čakovec back into their local community.

The origins of ACT lie primarily in the Croatian punk scene and its rejection of mainstream social organisation. ACT's initial activities were primarily oriented towards youth and culture. Concerned to fill the void in terms of cultural activities in the area and at the same time express their own interests and ideas, ACT's founders sought to involve young people in activism through a library 'Tabula Rasa' with a collection of fanzines and hard to obtain books on critical political thinking, activism and anarchism. They also started a youth club, primarily oriented towards promoting independent culture 
DRUŠ. ISTRAŽ. ZAGREB GOD. 26 (2017), BR. 2, STR. 143-163

STUBBS, P., VIDOVIĆ, D.: SOCIAL ENTERPRISE...

1 Public call advertised on June 7, 2006 at web portal of the National Foundation for Civil Society Development. Available at http://zaklada. civilnodrustvo.hr/categ ory/102/subcategory/
$126 / 585$ through literary events, discussions and book promotions, and musical events including concerts featuring primarily hard-core punk and related musical genres.

\section{First social enterprises}

In 2007, ACT made a formative move from being somewhat passive consumers of rebellious sub-cultural ideas to becoming active creators of new economic models. The establishment of ACT Printlab, a company for multimedia, graphics and web design, was a key moment in the development of social enterprises in Croatia. In 2009, another social enterprise, ACT Konto, specialising in accounting services for non-governmental organisations, was established. Both companies were registered as limited liability companies, but their organisational identities were more complex and hybrid, being subsidiary companies that reinvested any surplus into the programmes of the parent organisation responding to and meeting community needs. In practical terms, they were either giving grants or providing pro bono services to local NGOs. This was quite an unusual practice in Croatia at the time, looked upon with suspicion and bewilderment by public institutions. It was a practice which resulted in the loss of significant financial support from local authorities, cutting some 15,000 Euros in grant aid to the association ACT in 2010, on the grounds that the association could not possibly need the money, given that it was providing donations to others. Despite this, the practice has continued to be a key element of ACT Group's work, reflecting the principle of 'reinvesting in the local community'.

Association ACT's turn towards social entrepreneurship was influenced by a number of external factors. Crucially, in 2007, some 15 years of external support for building the so-called 'civil society' in Croatia, in conflict and post-conflict conditions, with significant donor support, mainly from the United States and Europe, channelled to emerging non-governmental organisations (Stubbs, 2012) was coming to an end. Although models of external financing of NGOs had paid lip-service to their 'sustainability', new funding models were being sought after by a number of donors as part of their 'legacy' and 'exit strategy'. One of the last calls for proposals of the USAID-funded Academy for Educational Development (AED) prioritised grants for "projects which will create creative models for finding new and diverse sources of financing for civil society organizations". 1 'New and diverse' sources of financing, of course, resonated with a broad neoliberal agenda of promoting 'responsible' self-sufficient civil society as the main vehicle for promoting social and economic development, suspicious of public provision and of 'inefficient' welfare states and, 
DRUŠ. ISTRAŽ. ZAGREB GOD. 26 (2017), BR. 2 STR. $143-163$

STUBBS, P., VIDOVIĆ, D.: SOCIAL ENTERPRISE... in their place, promoting 'creativity', 'innovation' and above all 'enterprise' as the preferred way to tackle social problems.

At around the same time, the Nonprofit Enterprise and Self-Sustainability Team (NESsT) had just begun work in Croatia, aiming to promote the development of social enterprises, a term which had hardly been used in public and policy discourse up to that point. Positioning itself as a typical 'meta-NGO', or as an organisation whose "primary purpose is to provide information and assistance to other NGOs" (Bach \& Stark, 2003), NESsT began to hold workshops, produce brochures and open calls for NGOs in Croatia to get involved in social entrepreneurship. The association ACT became both recipients of an AED grant and were amongst the first group of organisations supported by NESsT. For both AED and NESsT, association ACT ticked many of the right boxes, being a young enthusiastic NGO in an area with very few activist-led initiatives. They were far from 'cultural dopes' however, following passively all of the dictates of international donors and supporters.

Whilst lacking experience, the core group around ACT had a degree of confidence in building their own economic model, establishing a commercial entity overnight, quickly recruiting and employing a manager combining business experience with a commitment to the values of the organisation. The combination of risk-taking, awareness of their own limitations, and searching for out-of-the-box solutions while maintaining values of solidarity and transparency were clearly crucial.

\section{Core mission: social entrepreneurship}

A new phase, marked by a significant shift in ACT's mission and vision, began in 2010. Encouraged by the success of their social entrepreneurship projects, ACT decided to make 'social economy', or as they prefer to call it 'eco-social economy' and social entrepreneurship in particular, the main focus of their work. ACT managed to occupy several roles in this period: direct involvement in a growing number of social enterprises; as a key actor in creating an intermediary support sector; as a networking platform providing consultancy support to nascent social entrepreneurs; and as an advocacy organisation promoting social entrepreneurship in Croatia and lobbying for policy changes.

In this phase, a number of new enterprises emerged from ACT-led projects or from their participation in co-operative networks. The social cooperative Humana Nova was formed in 2011, a result of an EU-funded project of professional retraining for vulnerable hard-to-employ groups in Međimurje 
DRUŠ. ISTRAŽ. ZAGREB GOD. 26 (2017), BR. 2, STR. 143-163

STUBBS, P., VIDOVIĆ, D.: SOCIAL ENTERPRISE...
County, employing socially excluded individuals in the production and sale of innovative textile products made of recycled materials. By 2012, the enterprise had 11 employees, mostly women with disabilities, and was the first re-use venture in Croatia based on the co-operative form as a business model. Humana Nova quickly became one of the most recognizable ACT brands, although the lack of high quality products eroded customer loyalty and reduced incomes. Humana Nova went through a very turbulent period, exacerbated by the cutting of funding they were expecting to receive from the European Social Fund in 2015-2016, in the wake of political shift in Croatian politics, resulting in a new right-wing coalition that, in its short time in office, cancelled many projects in the fields of youth, social policy and independent media. To survive, they introduced temporary minimum wages for employees, and reoriented their core business to sewing services primarily for business clients, putting production of 'innovative eco-fabric products' on the back burner.

ACT Group's second co-operative venture was CEDRA Cakovec established in 2011, one of the founding members of the Cluster for Eco-Social Development officially registered in 2013, which provides consultancy services for social enterprises and beyond. The CEDRA Cluster gathered organisations from four Croatian cities: Čakovec, Osijek, Rijeka and Split, with a history of collaborating together on social enterprise promotion. Through CEDRA Čakovec, ACT institutionalised its role as an advocate for social entrepreneurship development. The Cluster was instrumental in initiating the development of a national strategy for social entrepreneurship finally adopted in 2015, which was more transparent and inclusive than many similar strategies.

Jointly with Međimurje County, ACT Group also established the Centre for Home Care in 2014, as part of an EU-funded social welfare project. The Centre provides various services to older and disabled persons in their home, and is a model of deinstitutionalisation of social services. At the moment, the Centre employs three persons and is a rare example of a public-private partnership in the social sector, the first substantive partnership between ACT Group and local authorities (ACT Group, 2015a).

In 2014 another EU-funded social enterprise 'Domači vrt' (Home Garden) was established to promote the social inclusion and employment of Roma people through biodynamic agriculture. Among the founder-owners are four Roma persons, maintaining focus on the social integration of the significant Roma minority in Međimurje. After starting well, the co-operative faced difficulties in finding a manager willing to 
DRUŠ. ISTRAŽ. ZAGREB GOD. 26 (2017), BR. 2 STR. 143-163

STUBBS, P., VIDOVIĆ, D.: SOCIAL ENTERPRISE.. work with the Roma minority. Recently, however, two agronomy experts were employed together with five Roma persons, suggesting the possibility of gradual development.

\section{Creating the Consortium}

In 2013 ACT Group decided to establish a Consortium with a single identity, gathering all of its organisations together, not just for 'brand recognition' but also to share human, financial and other resources. ACT Group affiliates the remaining independent organisations, each controlled by their members according to the principle of 'one member - one vote'. Members operate on the market, and are encouraged to have positive economic performance. However, the distribution of profit or surplus is limited and members themselves decide where to re-invest net income or surplus. The values which the organisation promotes are clearly stated: personal responsibility, openness, participatory approach, solidarity, cooperation, and transparency (ACT Group, 2015b). When describing the reasons for establishing a Consortium, many informants emphasised that it was a "natural, organic growth", allowing for great mutual support between entities.

Building a self-sustainable community can be read as ACT Group's attempt to protect themselves in an unstable environment, through the creation of a new and innovative system of internal financing. They have established four funds that enable mutual savings and use of joint financial reserves: a Mutual assistance fund, a Solidarity fund, a Development fund and a Reserve fund, with specific procedures prescribed for each. Contributing to most of the funds, with the exception of the Mutual assistance fund, is obligatory for all individual members in prescribed amounts or as a percentage of salary, but is not experienced by staff as overly complex or as a burden. Besides the funds, the consortium has enabled members to develop a model of joint financial governance and therefore to access money when facing difficulties, enabling survival even in crisis conditions.

\section{Key analytical themes}

\section{Preserving an "oppositional" identity}

Initially, as we have seen, ACT gathered young people attracted by alternative lifestyles and alternative ideas on society, technology, and the economy. At that time, it became a local platform for alternative culture, positioned in opposition to mainstream cultural patterns and hegemonic ideology. The narrative used to describe their interests and activities included: 'independent', 'open-source', 'open-culture, 'non-institutional culture', and 'alternative life-styles', gathering those 
DRUŠ. ISTRAŽ. ZAGREB GOD. 26 (2017), BR. 2, STR. 143-163

STUBBS, P., VIDOVIĆ, D.: SOCIAL ENTERPRISE... committed to 'human rights', 'animal liberation', and 'environmental sustainability', and embracing practices of 'autonomy' and 'voluntarism'. The first phase was defined primarily in terms of cultural and sub-cultural politics, emerging from, and influencing the development of an independent punk and anarchist cultural scene in north-western Croatia.

As these young punks grew older, while still influenced by critical anarchist thinkers including Kropotkin and in particular articulating their antagonistic relationship to capitalist neoliberal hegemony via Proudhon's thought, they became increasingly interested in the ideas of co-operatives and of worker's self-management, tracing these in and beyond a Yugoslav socialist context, as practical ways of realising alternative forms of economic organisation. At the same time, in what can be regarded as a 'perverse confluence' these positions were linked with a growing interest in an emerging discourse on 'social entrepreneurship' as a practical means of tackling important social problems.

The move from more 'revolutionary' to 'reformist' aims, marked by establishing the first social enterprise, is seen by some respondents as a product of the process of maturing:

"As we became older we changed our views, and ... you upgraded yourself and now you know that you cannot change the world. You can change yourself and you can change your local society." (Informant 1, managerial position, 2015)

As young 'rebels', they saw in models of social entrepreneurship a practical way to initiate social change, embracing values of democratic governance, community, solidarity, innovation, creativity and social inclusion, extending the not-for-profit form in ways which remained compatible with a critique of neoliberal economics:

"We wanted to make something different from capitalist companies... (We saw) how they don't care for their workers and how they don't care for the people they sell their products to... We wanted to make things better..."

(Informant 1, managerial position, 2015)

Once the development of social entrepreneurship became a core orientation, ACT's social enterprises received external recognition, particularly in the context of Croatia's accession to the European Union. The 'Europeanisation' of 'social entrepreneurship' increased the use and misuse of the concept within Croatian public policy, where it became something of an 'empty signifier', a new development panacea, much as 'civil society' had been a decade earlier. However, support for 
DRUŠ. ISTRAŽ. ZAGREB GOD. 26 (2017), BR. 2 STR. 143-163

STUBBS, P., VIDOVIĆ, D. SOCIAL ENTERPRISE... social entrepreneurship was more rhetorical than real, with little coherent development of a supportive policy environment. ACT Group was able to exploit this policy vacuum, occupying a space as an enthusiastic promoter of the concept, offering concrete support to other social enterprises, a status amplified by the tendency to pick up national and international awards in recognition of their efforts.

Whilst ACT has not been immune to problems caused by market instabilities, limited human resources and an inconsistent and unsupportive institutional environment, these have not threatened their social enterprise identity. On the contrary, they have strengthened that identity and reinforced a commitment to continue in the face of those who do not understand what social enterprise is, and do not understand ACT Group. This confrontational approach has enabled the Group to continue to present itself oppositionally, as a misunderstood agent of social change and against the mainstream socio-cultural and economic environment:

\footnotetext{
"There is always a hidden perception of us as those 'who do some things for themselves' ... And they don't see or understand that what we are doing is for the community, for the social and economic development of the community, for the benefit of all citizens." (Informant 2, managerial position, 2015).
}

\section{'Non-hierarchy' in practice}

Throughout, ACT has coped with an inconsistent legal and institutional environment by ensuring that its own values of solidarity, transparency, and co-operation have been strengthened, contributing to the durability and endurance of the organisation itself. ACT Group has tended to formalise its values within new entities and through creating new procedural mechanisms, shaping their own idea of the 'good economy' rather than copying models from elsewhere. Some institutional solutions appear more sustainable than others, however. Indeed, mechanisms created to ensure participatory governance, mutual responsibility and solidarity have sometimes been perceived as a burden:

"Here... often they plan something, there is so much planning... (sigh) ... And when it comes to applying... it fails to happen." (Informant 3, non-managerial position, 2016)

This is most clearly illustrated in the case of Humana Nova, where ACT Group sought to create a co-operative run by worker-owners, responsible for all strategic decisions in the company. Those employed were often both unfamiliar with 
DRUŠ. ISTRAŽ. ZAGREB GOD. 26 (2017), BR. 2, STR. 143-163

STUBBS, P., VIDOVIĆ, D. SOCIAL ENTERPRISE... and not particularly committed to the idea of democratic governance:

"Humana Nova is maybe not a good example of worker's self-governance. Humana Nova has just started moving in that direction. We are building capacities. Actually, employees are learning to do that. They are learning to listen, to communicate. They are learning to use the freedom they have to govern the venture." (Informant 2, managerial position, 2013)

In many ways, a commitment to 'non-hierarchy' reflects a kind of 'laissez-faire' approach, relying on individual responsibility as a key value. In practice, this usually means joint managerial agreement around specific objectives and activities, with their realisation left to employees. Mentoring and support is either weak or completely absent, so that 'freedom to act' can become more a source of anxiety and uncertainty than a source of empowerment:

"People don't like to have that much freedom... because, then they will feel lost. They prefer to know more what needs to be done, to have someone to control them, to experience more governing..." (Informant 4, non-managerial position, 2016)

In practice, the absence of formal hierarchy results in a lack of clearly defined roles and responsibilities, a legacy perhaps of an NGO mind-set. Project-oriented activities still dominate with the majority of employees seeing themselves as activists. Democratic governance seems to be difficult to achieve, despite institutionalized processes which seek to enable it. There are ambivalent and quite contradictory attitudes and behaviours towards the value of participatory governance, with employees both reluctant to participate more in decision making, but also protesting when excluded from decision-making processes.

\section{Charismatic leadership}

Thus far, the creation of a consortium ACT Group has not significantly improved the group's public visibility, creating more confusion than clarity regarding the different components of the group, and their inter-relationships. If anything, the 'identity' of ACT Group is now even more synonymous with its founder, widely perceived as a charismatic leader responsible for the group's key initiatives, and occupying a space of both formal and informal leadership. Now the director of ACT Group, the founder has held various managerial positions in the original ACT and its spin-offs, and is very much the public face of ACT Group in the media: 
DRUŠ. ISTRAŽ. ZAGREB GOD. 26 (2017), BR. 2 STR. 143-163

STUBBS, P., VIDOVIĆ, D.: SOCIAL ENTERPRISE...

\section{CONCLUSIONS}

"ACT Group... I don't think it's recognised that much... Most often they have heard about (founder), and then they recall - Aha! (founder), ACT, Čakovec..." (Informant 4, non-managerial position, 2016)

The issue of 'leadership' in social enterprise is an important one. Many involved in ACT Group have stated that they "cannot imagine ACT Group operating without (founder)", that "everything would fall apart without him", or even admitting that they are not sure whether they would have joined or stayed if the founder were not there:

"I was actually thrilled to work here after I spoke with (founder), who interviewed me. Before that, other employers would refuse to employ me, when I told them that I am still studying and want to finish. (Founder) was, to my surprise, so supportive, and he gave me the job. (...) I still think he is a great person, even though we disagreed sometimes, and I appreciate the experience gained in ACT." (Informant 5, non-managerial position, on leave, 2016)

"(Founder) made me fall in love with social entrepreneurship." (Informant 6, managerial position, 2016)

The founder is consulted informally on a daily basis by colleagues and employees, often with little regard for his formal role and sidestepping normal channels of decision-making. In many ways, the lack of formal hierarchy within ACT Group is combined with strong reliance on a single charismatic leader playing multiple roles and therefore ultimately reinforcing a different kind of hierarchy. The intensification of formalisation within ACT Group during the last decade has, to all intents and purposes, coincided with the continued leadership of one person. The contradiction between the collective spirit of ACT Group and the individualised embodiment of this in the form of its charismatic leader is striking. ACT Group continues to be enrolled, then, within a model of the 'heroic' social entrepreneur, although in the end, it may be as much the hybridity and multi-facetedness of ACT Group which accounts for its resilience in a difficult operating environment.

We have addressed some key elements of the complexity and hybridity of the social enterprise form and in particular the gap between stated intentions and 'on the ground' practices. The need for continued reflection is particularly striking amongst those seeking to develop sustainable social enterprises, particularly in fluid or under-developed operating environments. This retrospective presentation of a pioneering social 
DRUŠ. ISTRAŽ. ZAGREB GOD. 26 (2017), BR. 2, STR. 143-163

STUBBS, P., VIDOVIĆ, D.: SOCIAL ENTERPRISE...

\section{REFERENCES}

enterprise in Croatia can be complemented in future by other case studies building towards a comparative understanding of the lived practices of a wider range of social enterprises, exploring the complex articulations between organisation forms and structural possibilities. The study has at least shown the importance of going beyond simplistic and one-dimensional understandings of either heroic experimentation or the unfettered reproduction of neoliberalism which all too often frame accounts of social enterprise.

The case illustrates the multifaceted complexity of organisational processes over time, seen as a continuing battle to ensure sustainable internal functionality, as well as a flexibility to respond and adapt to an external environment which, in transition contexts, is inconsistent and often unsupportive. ACT's social enterprise practice, with its origins in an explicit 'oppositional' identity, contains hybrid aspects, seeking to 'make a difference' without abandoning a critical stance towards the dominant for-profit economic model. The study also provides insights into the shifting dynamics of formality and informality, on the one hand, and hierarchy and non-hierarchy on the other. There is much more going on than merely the co-existence of a formal rejection of hierarchy alongside significant informal hierarchical structures of decision-making. Legacies of participatory governance within workers' self-management from the times of socialist Yugoslavia prove difficult to maintain and adapt in the face of contemporary democratic deficits and a push towards continual 'social innovation' and survival of the fittest in the (quasi-)market. To an extent, the challenges of collective governance are compensated for in the role of charismatic leader, whose multiple roles, visionary leadership and deep commitment actually reinforce collective imaginaries rather than erode them. As noted above, more studies are needed to explore these elements across a wider range of cases and contextual conditions.

ACT Group (2015a). Annual report on ACT Group. Čakovec: ACT Group. ACT Group (2015b). Brochure on ACT Group. Čakovec: ACT Group.

Bach, J., \& Stark, D. (2003). Technology and transformation: Facilitating knowledge networks in Eastern Europe, Technology, Business and Society Programme, Paper 10, Geneva: UNRISD.

Blagojević, M. (2006). Knowledge production at the semi-periphery: A gender perspective. Belgrade: Institute of Criminology and Sociological Research.

Block, S. (2004). Why nonprofits fail. Overcoming founder's syndrome, fundphobia, and other obstacles to success. San Francisco: Jossey-Bass.

Bornstein, D. (1998). Changing the world on a shoestring. Atlantic Monthly, 281(1), 34-39. 
DRUŠ. ISTRAŽ. ZAGREB GOD. 26 (2017), BR. 2, STR. $143-163$

STUBBS, P., VIDOVIĆ, D.: SOCIAL ENTERPRISE...
Chisholm, D. (1989). Coordination without hierarchy: Informal structures in multiorganizational systems. Berkeley and Los Angeles: University of California Press.

Clarke, J. (2008). Living with/in and without neo-liberalism. Focaal, 51(1), 135-147. https://doi.org/10.3167/fcl.2008.510110

Clarke, J. (2010). After neo-liberalism? Markets, states and the reinvention of public welfare. Cultural Studies, 24(3), 375-394. https://doi. org/10.1080/09502381003750310

Clarke, J., Bainton, D., Lendvai, N., \& Stubbs, P. (2015). Making policy move: Towards a politics of translation and assemblage. Bristol: Policy Press. https://doi.org/10.1332/policypress/9781447313366.001.0001

Cook, B., Dodds, C., \& Mitchell, W. (2003). Social entrepreneurship False premises and dangerous forebodings. Australian Journal of Social Issues, 38(1), 57-72. https://doi.org/10.1002/j.1839-4655.2003.tb01135.x

Dagnino, E. (2007). Citizenship: A perverse confluence. Development in Practice, 17(4-5), 549-556. https://doi.org/10.1080/09614520701469534

Defourny, J., \& Develtere, P. (1999). The social economy: The worldwide making of a third sector. In J. Defourny, P. Develtere, \& B. Fonteneau (Eds.), L'économie sociale au Nord et au Sud (pp. 25-56). Paris: De Boeck.

Defourny, J., \& Nyssens, M. (2010). Conceptions of social enterprise and social entrepreneurship in Europe and the United States: Convergences and divergences. Journal of Social Entrepreneurship, 1(1), 32-53. https://doi.org/10.1080/19420670903442053

Dolan, C., \& Rajak, D. (2016). Introduction: Toward the anthropology of corporate social responsibility. In C. Dolan \& D. Rajak (Eds.), The anthropology of corporate social responsibility (pp. 1-28). New York: Bergahn.

Eikenberry, A. M., \& Kluver, J. D. (2004). The marketization of the nonprofit sector: Civil society at risk? Public Administration Review, 64(2), 132-140. https://doi.org/10.1111/j.1540-6210.2004.00355.x

European Commission (2011). Social business initiative: Creating a favourable climate for social enterprises. Brussels: European Commission.

Fine, G. A. (2003). Towards a peopled ethnography: Developing theory from group life. Ethnography, 4(1), 41-60. https://doi.org/10.1177/ 1466138103004001003

Fraser, N. (2009). Feminism, capitalism and the cunning of history. New Left Review, 56, 97-117.

Gibson-Graham, J. K. (2006). A postcapitalist politics. Minneapolis: University of Minnesota Press.

Gould, J. (2004). Introducing aidnography. In J. Gould \& H. Secher Marcussen (Eds.), Ethnographies of Aid: exploring development texts and encounters. Roskilde: University Institute for Development Studies.

Krajina, Z., \& Blanuša, N. (Eds.) (2016). EU, Europe unfinished: Mediating Europe and the Balkans in a time of crisis. London: Rowman \& Littlefield.

Larner, W. (2015). The limits of post-politics: Rethinking radical social enterprise. In J. Wilson \& E. Swyngedouw (Eds.), The post-political 
DRUŠ. ISTRAŽ. ZAGREB GOD. 26 (2017), BR. 2, STR. $143-163$

STUBBS, P., VIDOVIĆ, D.: SOCIAL ENTERPRISE... and its discontents: Spaces of depoliticisation, spectres of radical politics (pp. 189-207). Edinburgh: University Press.

Leadbeater, C. (1997). The rise of the social entrepreneur. London: Demos. Lendvai, N., \& Stubbs, P. (2007). Policies as translation: Situating transnational social policies. In S. M. Hodgson \& Z. Irving (Eds.), Policy reconsidered: Meanings, politics and practices (pp. 173-190). Bristol, Policy Press. https://doi.org/10.1332/policypress/9781861349132. 003.0010

Lloyd, P. (2007). The social economy in the new political economic context. In A. Noya, \& E. Clarence (Eds.), The social economy. Building inclusive economies (pp. 61-90). Paris: OECD. https://doi.org/10.1787/ 9789264039889-4-en

Marcus, G. E. (1995). Ethnography in/of the world system: The emergence of multi-sited ethnography. Annual Review of Anthropology, 24, 95-117. https://doi.org/10.1146/annurev.an.24.100195.000523

McMahon, T. (2008). Social construction of charismatic leadership: A case study. PhD thesis. Ann Arbor: Proquest, Umi Dissertation Publishing. McRobbie, A. (2011). Rethinking creative economy as radical social enterprise. Variant, 41, 32-33.

Muehlebach, A. (2012). The moral neoliberal: Welfare and citizenship in Italy. Chicago: University of Chicago Press. https://doi.org/10.7208/ chicago/9780226545417.001.0001

Newman, J. (2012). Working the spaces of power: Activism, neoliberalism and gendered labour. London: Bloomsbury Academic.

Olma, S. (2016). Fair city: Beyond the ideological trinity of innovation. Amsterdam Alternative 6. Available at http://amsterdamalterna tive.nl/articles/1890.

Smith, D. (2005). Institutional ethnography: A sociology for people. Lanham: AltaMara Press.

Spear, R. (2010). Social entrepreneurship and social movements, Skoll Colloquium on Social Entrepreneurship, Oxford, June. Available at https://www.academia.edu/4183726/Social_Entrepreneurship_and_ Social_Movements

Spry, T. (2009). Bodies of/as evidence in autoethnography? International Review of Qualitative Research, 1(4), 603-610.

Stubbs, P. (2012). Networks, organisations, movements: Narratives and shapes of three waves of activism in Croatia. Polemos, 15 (2), 11-32.

Stubbs, P. (2015). Performing reform in South East Europe. In J. Clarke, D. Bainton, N. Lendvai, \& P. Stubbs, Making policy move: Towards a politics of translation and assemblage (pp. 65-94). Bristol: Policy Press. https://doi.org/10.1332/policypress/9781447313366.003.0003

Šimleša, D., Puđak, J., Majetić, F., \& Bušljeta Tonković, A. (2015a). Across the borders: Social economy in Europe. Zagreb: Institute of Social Sciences Ivo Pilar.

Šimleša, D., Puđak, J., Majetić, F., \& Bušljeta Tonković, A. (2015b). Mapping new horizons: Report on the state of social entrepreneurship in 
DRUŠ. ISTRAŽ. ZAGREB GOD. 26 (2017), BR. 2 STR. $143-163$

STUBBS, P., VIDOVIĆ, D.: SOCIAL ENTERPRISE...

* Istraživački pristup koji rabi i spaja informacije prikupliene kroz razne uloge u koje istraživač ulazi.
Vidović, D. (2012). Socijalno poduzetništvo u Hrvatskoj (Social entrepreneurship in Croatia), PhD thesis. Zagreb: Faculty of Humanities and Social Sciences.

Vidović, D. (2013). Social entrepreneurship in Croatia: A framework for development. Euricse Working Papers No. 61/13. https://doi.org/ $10.2139 /$ ssrn.2367388

\section{Socijalno poduzeće u tranziciii: studija slučaja ACT grupe}

\section{Paul STUBBS}

Ekonomski institut, Zagreb

Davorka VIDOVIĆ

Fakultet političkih znanosti, Zagreb

Kontekstualiziranje socijalnoga poduzeća kao "življenih praksi" nadvladava krute binarnosti između idealiziranja takvih pothvata kao "herojskih" te onih koji ih vide kao reprodukcije neoliberalne hegemonije. U kontekstu "tranzicijskih" društava s "polu-periferije" potrebne su studije slučaja socijalnih poduzeća usmierene na mikrorazine življenih društvenih praksi. Takve bi studije istražile načine na koje pojedine inicijative utiru put, ma koliko to bilo proturječno i paradoksalno, prema nezavisnom prostoru za djelovanje, čak i unutar nedosljednog i nepodržavajućeg okruženja. Rad se temelii na bending and blending* pristupu, koristeći se činjenicom da su istraživači socijalnih poduzeća neizbježno uključeni i kao savjetnici u kreiranju politika, zagovornici te sudionici i praktikanti. Primjenom kvalitativne metodologije, rad istražuje djelovanje ACT grupe, konzorcija socijalnih poduzeća iz Čakovca, nastojeći razumjeti hibridnost organizacijske topografije i stilova upravljanja, složene odnose između formalnih i neformalnih praksi te neočekivane sinergije između karizmatskoga vodstva i kolektivnog odlučivanja.

Ključne riječi: socijalno poduzeće, Hrvatska

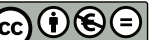

Međunarodna licenca / International License:

Creative Commons Attribution-NonCommercial-NoDerivatives 4.0. 